International Journal of Linguistics, Literature and Translation

ISSN: 2617-0299 (Online); ISSN: 2708-0099 (Print)

DOI: 10.32996/ijltt

Journal Homepage: www.al-kindipublisher.com/index.php/ijltt

\title{
Contact-induced Phonological Change of the Phoneme /s/ in the Speech of EFL Learners and Teachers in Algeria: A Case Study
}

\author{
Ali Berrabah 19 (D) $\triangle$ and Ammar Benabed ${ }^{2}$ (D) \\ 'Junior lecturer (Assistant Professor) at the Section of English, Department of Foreign Languages, Faculty of letters and \\ languages, Ibn Khaldoun University of Tiaret, Algeria \\ ${ }^{2}$ Senior lecturer (Associate Professor) at the Section of English, Department of Foreign Languages, Faculty of letters and \\ languages, Ibn Khaldoun University of Tiaret, Algeria
}

$\triangle$ Corresponding Author: Ali Berrabah, E-mail: berrabah84@gmail.com

ARTICLE INFORMATION ABSTRACT

Received: April 12, 2021

Accepted: May 21, 2021

Volume: 4

Issue: 5

DOI: $10.32996 /$ ijllt.2021.4.5.13

\section{KEYWORDS}

EFL, ELT, Contact-induced change, Language planning/policy in Algeria
This paper investigates the phenomenon of contact-induced phonological change of the phoneme /s/ in the speech of EFL learners and teachers at the secondary schools and even Higher Education in Algeria. It is perceived that the letter ' $s$ ' is recurrently pronounced / $\mathrm{z} /$ whenever it is positioned between two vowel sounds and that the double -ss- between two vowels is simply uttered /s/ in many words. This fact is attributed to the overgeneralization of French phonological rules however this is not the case in English. Such phonological aspects have become prominent symptoms within English as Foreign Language (EFL) classrooms prior to French overuse within Algeria's speech repertoire due to historical and practical reasons. This study seems as a departure from the meeting point of looking at such phenomenon in teachers and/or learners' natural conversations in EFL classrooms to a critical examination of its uses in numerous English terms. To attain this, Labov's "observer's paradox" (1972) was considered to overcome problems while collecting spontaneous speech data. Two different strategies were employed, structured and unstructured observations, throughout thirteen years. A total random sample of 257 respondents had been included, 204 of whom are secondary school pupils and university students, and the remaining are secondary school (trainee) teachers and university lecturers. The first group was intentionally asked to derive either nouns or adjectives from a range of words containing phoneme /s/, classify some words in a table according to the final '$d^{\prime}$ pronunciation or give the opposites -especially using the prefix 'dis_' - to certain words keeping the same root as well pronounce them at the end. The second group was recorded. Outstandingly, the study concludes that $98 \%$ of our informants mispronounce the given words. At last, some recommendations have been suggested to alleviate the problem.

\section{Introduction}

The phenomenon of contact between the world's language varieties has become, in the light of the requirements of globalization, a must for any society to develop. Since languages cannot thrive in total isolation, language contact situations have been regarded as leading forces in the structural changes of many substrate varieties. Going back to its very long recorded history, Algeria has always been considered a hotbed of many successive colonial civilizations that is it had witnessed the existence of multiple cultural waves. The closer contact of such civilizations with the local culture and language varieties has resulted in a linguistic mosaic and a multicultural identity in the country. Thus, many of its coexisted language varieties have been subjected to contact-induced morpho-syntatic and sometimes phonological changes through time. Undeniably, no other colonial power has had significant impacts on the socio-cultural, economical, linguistic and political levels as France in Algeria. In view of that, this

\section{K C AL-KINDI CENTER \\ R D FOR RESEARCH AND DEVELOPMENT}

Your gateway to world-class research

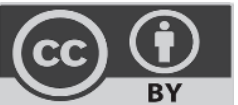

Published by Al-Kindi Center for Research and Development, London, United Kingdom. Copyright (c) the author(s). This open access article is distributed under a Creative Commons Attribution (CC-BY) 4.0 license 
study focuses on a thought-provoking subject matter that is contact-induced phonological change of the phoneme $/ \mathrm{s} /$ in the speech of both EFL learners and teachers in Algeria. Such phenomenon is credited to the overgeneralization of the French phonological rules that the letter ' $\mathrm{s}$ ' is frequently pronounced / $\mathrm{z} /$ once it is placed between two vowel sounds and that the double -ss- amid two vowel sounds is simply uttered / $\mathrm{s} /$ in any word but this is not the case in English. Since our interest is based on the inner contact-induced phonological change and/or the mispronunciation of the phoneme /s/ amongst EFL learners and some of their teachers, we will endeavour to answer a number of key questions such as:

a) To what extent do language contact and the long term of acculturation between French and Arabic affect ELT in Algeria?

b) What measures should be taken by decision-makers and/or curricula designers to overcome such and other similar problems in ELT in the Algerian context in future schooling reforms?

c) What are the possible strategies that both EFL teachers and learners should follow to improve their pronunciations in general and mainly in detecting and/or correcting the mispronunciation of the phoneme $/ \mathrm{s} /$ in their speech?

The ultimate objectives of the current study are:

1. To determine some other factors or substantial reasons behind the overgeneralization of some French phonological rules in English inside EFL classrooms in Algeria.

2. To suggest possible solutions to problems created by the imbalance between integrating the four skills in ELT curricula or handicaps related to their applications inside classrooms.

3. To provide recommendations to enhance EFL learners' pronunciation ability through offering clues and/or hints in an attempt to get right of it from the start.

\section{Literature Review}

Just for the sake of simplification and clarification for the question of how the phoneme $/ \mathrm{s} /$ is mostly mispronounced whenever it is positioned in between two vowel sounds by both EFL learners and, unfortunately, many of their teachers in Algeria, it seems of paramount importance to include two main broad but related aspects: the first one begins by looking closely at the phenomenon of language contact between the different language varieties that compose the current linguistic and/or speech repertoire in Algeria with a particular reference to the way the process of acculturation between Arabic and French has deeply affected the pronunciation of many sounds of the coexisted varieties. The second part discusses the evolution of English as a Foreign Language (EFL) within Algeria's language planning/policy and English Language Teaching (ELT) through its various curricula reforms along with textbooks revision.

\subsection{Language Contact, Language Policy and French Immanence in the Speech Repertoire in Algeria}

By and large, language contact (aka contact linguistics) occurs in social situations where speakers of different language varieties, which can be genetically related or unrelated, interact with one another. In other words, contact linguistics refers to any circumstances in which speakers who belong to dissimilar cultures come into contact and the structural systems of their language varieties influence each other. (cf., Thomason \& Kaufman, $1988 \&$ Thomason, 2001, p. 2).

As a matter of fact, language contact situations have sometimes led to the creation of totally new varieties of languages besides resulted in a myriad of (socio)linguistic outcomes such as diglossia, borrowing, code-switching, code-mixing, etc., which have turned out to be fruitful areas of investigation. Such linguistic processes have aroused the curiosity of many researchers and generated an extensive body of research in different points across the globe. Along these lines, language contact has then become a two edge-sword concept.

On the one hand, language contact has been considered a rather positive phenomenon since it "is everywhere and there is no evidence that any languages have developed in total isolation from other languages" (Thomason, 2001). On the other hand, albeit contact linguistics is viewed as a creative force; contact-induced change - in which one alternative linguistic aspect or more take place - has been identified amongst the major problems that may distort the morpho-syntactic or the phonological systems of a lot of substrate varieties, i.e. several speakers in language contact situations may misunderstand or miscomprehend their coparticipants because of such linguistic changes.

Since Algeria is the gateway between Africa and Europe across the Mediterranean, it has been at the crossroads of many civilizations and military invasions, including the Phoenicians (1250 BC-105 BC), Romans (106 BC- 430 CE), Vandals (430-Mid of 7th CE), Arabs (Mid of 7th CE), Ottomans (1514-1830) and the French (1830-1962) respectively. Thus, throughout the course of its history, it has seen different cultural interactions and multiple linguistic influences.

It should be pointed out that the French colonialism, amongst all those cultures and civilizations, has the lion's share of profound changes in the morpho-syntactic, semantic and phonological aspects of Arabic (mainly Algerian Dialectal Arabic ' henceforth 
$\mathrm{ADA}^{\prime 2}$ ) and the coexisted language varieties such as Berber/T(h)mazight and its varieties ${ }^{3}$, Turkish, Spanish, English, German, etc. One might also say that the immanence of the French language (henceforward Fr) within the Algerian speech repertoire has revealed a deep impact mainly on the (socio)linguistic scope and even on the cultural dimension and has revolutionized the economic as well as political levels during the post-independent epoch of Algeria's different speech communities.

Historically speaking, the acculturation and the linguistic contact between Arabic and French started since its colonization on July 05, 1830. Since then, the Algerians (both Arabs and Berbers) were obliged to use French at least with the colonists, rather than their local varieties. Since the early years of its existence, France strived in a bald attempt to strip the Algerians of their fundamental national principles, including their language, religious values and cultural identity. For doing so, France built schools and encouraged children to join them via creating an environment conductive to learning Fr while restricting the traditional Koranic schools.

It seems that the 1930s law, decreeing Fr as the unique language to be used in the Algerians' everyday speech and in all domains at the expense of both Arabic and Berber/T(h)amazight that were totally restricted and declared as means of illiteracy, was a turning point in taking roots of Fr in the Algerian linguistic repertoire. This law was strongly opposed by the large majority of people, whose voices were represented by the ideas of some Muslim scholars of the nation' (known in Arabic as 'Ulamaa ElUlama'), which consists of a lot of elites, religious men and teachers like Abdelhamid Ibn Badis, El Bachir El Ibrahimi, Tayeb El Okbi, El Arbi Tebessi and others) and then were transmitted into armed uprisings by some national activists and leaders of National Liberation Front (FLN) like Ferhat Abbass, Messali El-Hadj, etc.

All those prominent figures and personalities adopted the slogan "L'Islam est notre religion, I'Algérie notre parties, la langue Arabe est notre langue." (Islam is our religion, Algeria is our homeland, and the Arabic language is our mother tongue). Accordingly, they believe that such provocative law deprives the Algerians' right of using freely their local varieties. Besides, they insist that the imposed language denies the basic components of Algeria's socio-cultural co- building, Islamic principles and national identity that is the Arabic language. Therefore, the only key and/or the purely efficient means to stand against the success of that colonial project has been Arabic revitalization and/or revival that could be only done by intensifying the activities of Zaouias (rural Koranic schools), whereby Modern Standard Arabic (hereafter MSA ${ }^{4}$ ) had to be taught for restoring the precolonial tongue, personal identity together with Arabo-Islamic culture. Things remain the same until the wake of independence in 1962 i.e., Fr was hardly ever used whilst the local varieties preserved their status in the Algerians' daily speech except for urgent situations.

Strangely enough, Ben Bella's first post-independent government (1962/65) reluctantly decided to include French in primary schools on an equal footing with Arabic. Thus, the first Constitution of 1963 shortly reviewed the decision via implementing 'the Arabization Policy' (in Arabic: التعريب t d: ri:b/) as an ambitious plan to revitalize Arabic across fading away French from the speech of the Algerians. Boumediane's subsequent government (1965/78) too insisted on the policy to revive the Arabic language, herein MSA, in the Principle Constitution of 1976 in which it was ranked as the only 'official language' as an attempt to reinstate the glories of Arabic and thus the Islamic values and cultural heritage.

Albeit 'the Arabization Policy' has been seen a goodwill gesture for restoring the Arabo-Islamic cultural identity and mainly to completely eliminate Fr from the Algerian linguistic repertoire, its implementation has been faced by two persistent obstacles. First, ADA, which has the biggest slice of the cake within the speech repertoire whereby "80\% of the whole population" use it in their everyday life (Boucherit, 2002, p. 56), has been substituted by MSA, which has never been used in is currently restricted in few domains like the primary and secondary schools, law and some administrations. In this respect, it is worthy to note that the expression 'the Arabic language' in the third amendment in all Constitutions, which certainly refers to MSA, sounds somehow misleadingly labelled and/or vaguely used in the sense that:

The Algerian sociolinguistic profile is renowned for ranking the Arabic language as the national and official language of all Algerians, up till now the most amazing thing is that the term Arabic here is

\footnotetext{
2 The local variety and the 'mother tongue' of most speakers (aka 'Darija' or 'El-Amiyya). It is used in informal every day speech and/or spontaneous communicative/oral situations. It is just a mixture of a regional Arabic and French together with the insertion (adoption or adaptation) of single words or expressions from others varieties including; Spanish, Turkish, English, etc.

${ }^{3}$ First preambled to the Algerian Constitution in 1997. On February 2002, president Bouteflika recognized T(h)amazight as a 'National' language in a constitutional amendment. Then, it was ranked as an 'Official' language in the fourth article of the Constitution of March 2016 and reconfirmed in the Constitution of November 2020. It is spoken by the "minority of 20\% of the whole population." (Boucherit, 2002, p. 56) ${ }^{4}$ It is the simplified and the literary adapted form of the Classical Arabic (the very standard form of Arabic and the frozen variety that was revealed later throughout the Holy Koran /Qur'an) to suit modern time requirements in both formal written and spoken situations including printed, oral or electronic media, official speeches, political discourse, educational fields, modern publications, etc. It is the official language in most Arab speaking countries
} 
still fuzzy since it does not point out whether the dead CA is valid or MSA have to be used within formal settings (Berrabah, 2014, p. 16)

In view of the above states of affairs, MSA can be synonymously used with ADA and also alternatively be employed in both everyday speech and informal settings. Undoubtedly, this fact seems to be totally contrary to what reality says and/or what has obviously been perceived in the daily speech of the general public.

Second, 'the Arabization Policy' has been intended to stamp French out of the speech of the Algerians. This aspiration gives the impression of being a challenging task and has been "for the largely French-educated and non-Arabophone elite of the new independent government... a daunting task," (Mostari, 2004, p. 27). Without beating around the bush, one might proclaim the malfunction of such policy via standing on the fact that "In the intervening time, CA and/or MSA fails to be updated with modernity and technology, for one reason or for another, in certain spheres of civic life, where the French language is still prevailing such as in medicine, banking, insurance, telecommunication, press, etc. (Berrabah, 2014, p. 18). In the same line of thought, Akila (2001) stated that "French has become an elitist language, symbol of social success and remains omnipresent in the fields 'of the bank, of the economy and the opening up on the universal.' It does not remain only the language of the former colonizer." (as cited in Berrabah, 2014, p. 18)

Accordingly, Fr has been enthusiastically spread in all domains since the wake of independence even better than that in the colonial era to plainly confirm "that French was never imposed on the Algerian people as it has often been claimed by Algerian officials." (Bouamrane, 1986, p. 40).

When all's said and done, one can claim that French has never ever lost its status as being a 'lingua franca' in Algeria whereby the great majority of speakers shift back and forth easily and purposefully from Arabic to French in their daily interaction and many speak, read and write it proficiently in both formal and informal settings as if they were native speakers. Therefore, eliminating Fr from the speech of every Algerian is easier said than done since the process involves the removal of all that is Fr from ADA that would really take the wind out of the Algerians' sails.

\subsection{English Language Teaching and Learning in Algeria}

To keep up-to-date with the contemporary technology trends and ongoing scientific development, decision-makers have felt an overwhelming need to include other foreign languages besides $\mathrm{Fr}$ in the education system since the latter has unable alone to face the competitive pressures unleashed by globalization. Therefore, English has been suggested "as the magic solution to all possible ills-including economic, technological and educational ones." (Miliani, 2000, p. 13) due to it has acquired a reputation for being "a global language" (Cristal, 2008). The choice was based on the fact that English has turned out to be the most efficient communicative "practical tool" for getting hold of the key "working language" posts (Cristal, 2003, p. 426) even in the Algerian context, where "the French language has lost much of its ground in the sociocultural and educational environments of the country." (Miliani, 2000, p. 13). In the same line of thought, Bouhadiba (2002) stated that "English is gaining dominance in the oil sector, computing, and in the scientific and technological documentation." (p. 16)

Due to the unrivalled global position of English especially in the scientific disciplines, it has been proved that "any literate, educated person on the face of the globe is deprived if he does not know English." (Burshfield as cited in Louznadji, 2003, p. 78). Algeria, comparable to numerous nations around the world, has become aware of the significance of English Language Teaching (ELT) and English as Foreign Language (EFL) learning has accelerated since the independence and reached its zenith in the last decade of the twentieth century.

In the early beginning of the 1990s, Ali Ben Mohammed, the ex- Minster of the National Education, explicitly announced his opinion on replacing Fr in primary schools by English. Such a bold gesture was the reason behind his overthrow after what has known as the 1992 baccalaureate subjects leak scandal. Four months later, in contrast to what was implied, an opinion poll was initiated about whether preserving FFL or using EFL, as an alternative means, in the fourth grade of primary school. In the end, policy makers decided - without referring to parents' poll results - to maintain Fr; whereas, English was introduced in a few primary schools in the 1993/4 and those EFL pupils would study FFL at the seventh grade at fundamental schools.

It is until the 2003 School Reform, ELT had been totally removed from primary education but it has been introduced to first-year middle school pupils for four years instead of just two years in the previous Fundamental schooling system. Thus, ELT has come a very long way towards meeting that objective. The four years of EFL learning at middle schools is followed by another three years of the secondary schools. At the university level, English can be willingly studied as a major field (speciality) or it has been compulsory taught as an extra independent subject matter (of about at least one hour and a half per week) for all other specialities without exception. 
In the footsteps of Ali Ben Mohamed, the former minister of higher education and scientific research Tayeb Bouzid (April 2019January 2020) declared at Mentouri University of Constantine on July 8, 2019 that "French does get you anywhere!"(as cited in Bensouiah, September 14, 2019). In view of that, the university presidents have been instructed in the ministerial ordinance of July 12, 2019 to use Arabic alongside English instead of $\mathrm{Fr}$ in the head of all official documents and correspondences. On August 18, 2019, Bouzid restated in the national conference of the Algerian universities the English will be the only language of instruction in all the scientific subject fields (specialities). From that perspective, he suggested the idea on his Facebook account to be conducted in a students and lecturers opinion survey. Surprisingly, $94.3 \%$ of respondents were in favour of the proposal. Along these lines, Bouzid insisted that:

in order to increase the visibility of research in higher education institutions...and to open up to the international environment...it has been decided to set up a think-tank of specialists and administration officials to present proposals for promoting the use of English in teaching and research.

At long last, it should be noted that Bouzid's demarche has received mixed reactions from the public opinion and the large majority views it to be rather political and "it comes at the wrong time." 5 Besides, it seems to be a hasty decision in the sense that many errors were made both in many universities, faculties and/or departments' entrance signs and mainly by the administrators in some official documents due to mistranslation from Fr into English. Whatever the objections or supports to the idea, it is again for ELT in Algeria even it remains only ink on paper and its page was folded up once the minister was changed.

\section{Methodolog}

Aspiring a more comprehensive enquiry, this paper highly considered the dilemma facing (socio) linguists while gathering spontaneous speech corpora, which is referred to by Labov (1972) as 'observer's paradox'. Since this study falls in the realm of phonology - particularly in detecting the mispronounced /s/ in many words in the speech of the Algerians EFL learners and teachers, two different data collection strategies were employed, structured and unstructured observations, as follows:

First, secondary schools pupils and university students were asked in separate classes and evaluation sessions for more than thirteen years to either: (a) give the opposite meaning to some words keeping the same root especially the words that need the inflectional bound morpheme and/or the prefix 'dis-' especially the ones that start with: the schwa sound / $\boldsymbol{\partial}$ / including; able, abuse, advantage, affect, afforest, agree, allow, appear, appoint, approve arrange, array, associate, avow, the sound / a:/ as in arm, the sound / I/ like in embark, embody, embowel, enchant, enfranchise, engage, entangle, establish, illusion, infect, inherit,

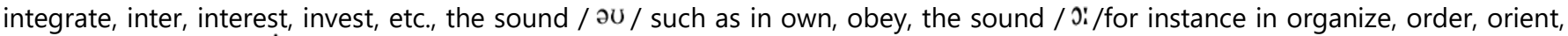
etc., and the sound $/ \mathrm{j} /$ for example in unite, use, etc. (b) derive either the nouns, adjectives or if possible the adverbs from a range of words among which use, abuse, base, isolate, obese, close(adj), advertise, exclusive, persist, precise, concise etc. (c) classify either the regular past form, regular past participle or certain adjectives derived from regular verbs from selected words in a table according to the pronunciation of their final '- $d$ ' suchlike based, increased, decreased, practised, cease, release, etc. Learners were invited to individually pronounce all words in each of the previous tasks to check the way the phoneme/s/ have been pronounced in such positions. It should be noted that data collection is built on each individual's exact pronunciation of the sound /s/ in at least four words.

Second, audios and videos recordings along notes taking have been separately collected over thirteen years now, at some stages in the speech and/or interaction of both secondary school EFL teachers and university lectures in multiple scientific events, including (tele) conferences, workshops, seminars, symposiums and examination boards of Masters Dissertations.

Being teacher-practitioners in the field, a lot of common ELT issues and many problems in language use inside and outside EFL classrooms have attracted our attention including the misspelling or mispronunciation of countless words, misuse of mechanics of writing, grammatical and/or structural errors. Such and other ELT and EFL learning-related problems have emerged in the Algerian context due mainly to negative transfer (aka language interference) or contact-induced change. What seems interesting to be dealt with yet worthy of being tackled in this investigation is the mispronunciation of the phoneme /s/ in numerous words inside secondary school EFL classes especially during the 'listening and speaking' or even 'reading' sessions, sound system activities (pronunciations of the final '-s- /- $d$ ', silent letters, matching pairs that rhyme, silent letters or marking or identifying the stressed syllables), oral role playing tasks, rubrics like 'words to say' and 'say it loud and clear'. The same problem can be observed in EFL students' speech at the university level mainly in 'phonetics and phonology' or 'listening and speaking' modules, 'reading comprehension' sessions and generally in any turn taken system during brainstorming or critical thinking phases, debates/discussions, and even at some stages in oral presentations and/or viva voces.

\footnotetext{
${ }^{5}$ Azzeddine Layachi, a specialist in the political science at St John's University in new York
} 
Moreover, attending various formative meetings on TEFL following the 2003 Secondary Education Reform for more than seven years and taking part in several national scientific events on specific themes related EFL and/or ELT in Algeria over six years now have aroused our curiosity about the way teachers and lecturers use English in interactions outside EFL classrooms. Such experience has provided insights into many linguistic phenomena that might be fruitful areas of investigations. Therefore, spontaneous speech recordings combined with notes taking have been considered in an attempt to recommend and/or suggest solutions to some of the language-related problems in ELT.

Since this study is mainly based on personal observations, audios and videos recordings together with notes taking, a random sample of $257 \mathrm{EFL}$ learners and teachers have been included. The target participants belong to different sexes and educational levels to adequately answer our research questions and meet our projected objectives.

\section{Results and Discussion}

This section is dedicated to discuss and interpret our finding from a statistical point of view. The analysis of our participants' personal information reveals that the $257 \mathrm{EFL}$ learners and teachers involved in the study are subdivided into four different groups according to divergent educational grades as follows: 76 (29.57\%) secondary school pupils, 128 (49.80\%) university students, 37 (14.39\%) secondary school teachers and 16 university lecturers including eleven (11) full-time assistant teachers, four 04 (06.22\%) PhD holders and one Professor. From a gender perspective, there are 143(55.65\%) females, who are split up according to their level of education into 41 secondary school pupils, 70 students, 21 secondary school teachers and 11 university lectures; whereas, the 114 (44.35\%) males are too divided up into 35, 58, 16 and 5 respectively. The imbalanced number amongst the two genders in our investigation may possibly be attributed to reinforce the shared stereotypes that females in Algeria try to learn/excel and do better in foreign languages if compared to males who do better in scientific subject matters. Besides, female teachers outnumber their equivalent males in the teaching/learning process in Algeria since school and/or university is regarded as the best workplace for women for many Algerians.

In the first question that was destined for the 204 pupils and students in the structured observation i.e. about giving the opposites keeping the same root via using the prefix 'dis-', which showed that no more than $2(0.98 \%)$ learners were able to pronounce the phoneme /s/ correctly in between the / $\mathrm{i} /$ of 'dis-' and the schwa sound / $\partial /$ in words like disagree. Just $4(1.96 \%)$ learners could utter/s/ right between the /i/ of 'dis-' and the sound / $\mathrm{a}$ // as in disarm. astonishingly, nobody (0\%) could pronounce the phoneme /s/ accurately amid the /i/ of 'dis-' and the sound / I/ like in disintegrate. Amazingly, a unique (0.49\%) learner enunciated /s/ perfectly between the / $/$ / of 'dis' and the sound / $\partial 0 /$ such as in disobey. Unfortunately, Only 3 (1.47\%) vocalized /s/ perfectly between the $/ \mathrm{i} / \mathrm{of}$ 'dis-' and the sound / $\mathrm{O}: /$ for instance in disorganize and simply 5 (2.45\%) learners realised the $/ \mathrm{s} /$ properly between the $/ i /$ of 'dis-' the sound $/ \mathrm{j} /$ for example in disuse.

Likewise, results in the second question were scary and very demotivating because the large majority of learners that is 193 (94.60\%) failed in those word building tasks and very few i.e., $11(5.39 \%)$ were able to pronounce the sound $/ \mathrm{s} /$ at least in five derived words appropriately in words like: usage /ju:s I d3/, useful /ju:sf Ol/, abusive / כ bju:s Iv/, basic /be Is I k/, basis /be Is I $\mathrm{s} /$, isolation/aisəlei $\int$ ən/, obesity /əubi:s I.ti/, closeness /kləusnəs/, advertisement /ədv3:t Ismənt/, etc.

As far as the third question on classifying selected words in a table according to the pronunciation of their final '- $d$ ' is concerned, amongst the 204 target population, only 7 (3.43\%) could classify words like based, increased, decreased, practised, ceased, released, etc. in the precise column i.e. pronounced as $/ \mathrm{t} /$ confirming that the $/ \mathrm{s} / \mathrm{sound}$ at the end in all the aforesaid words is uttered /s/. Nevertheless, the remaining 197 (96.56\%) learners erroneously classified the same words in the /d/ column, claiming that the phoneme /s/ at the end in those words is uttered /z/, which is totally contrary to Standard English pronunciation.

Unfortunately, when learners were asked about the reasons behind pronouncing $/ \mathrm{s} / \mathrm{as} / \mathrm{z} /$ in such positions, almost all of them simply replied that they had accustomed to doing so because they had heard their teachers pronounced them that ways and said that they had not had dictionaries nor had been advised by teachers to go back to them from one time to another for checking their phonemic transcriptions. Moreover, they misguidedly confirmed that they learned in French that the letter ' $s$ ' has to be pronounced / $\mathrm{z} /$ whenever it is positioned in between two vowels and the double 'ss' between two vowels must be uttered $/ z /$ in any word and the same phonological rules can be applied to English.

On the same grounds, the findings of the unstructured observation demonstrated that 45 (92.98\%) of EFL secondary school teachers and university lecturers, unfortunately, mispronounced the $/ \mathrm{s} /$ sound especially between two vowel sounds in many familiar and the most frequently used words similar to the aforementioned ones.

In an attempt to understand the reasons behind the wrong pronunciation of the phoneme $/ \mathrm{s} /$ in such positions within teachers and lecturers' speech, we had concluded that most of those teachers had not studied 'phonetics and phonology' at university as required nor had the opportunity to exploit the audio visual aids as the widely prevail nowadays. Besides, almost all our participants assured that they had always heard their ELT instructors did so, seeing as the large majority of them were rather 
Francophone. Thus, they had blindly accustomed to imitate their ways of pronouncing all words without exception without bothering themselves and/or had never thought of checking the transcriptions in dictionaries, which could not be easily reached at that time. Unfortunately, some of them confirmed that the pronunciation of the phoneme /s/ in between two vowels as /z/ has also been taught to their pupils and students for several generations.

\section{Conclusion}

In fact, this study is highly interpretive because it has been undertaken for more than thirteen years whereby both EFL learners and English language teachers in two distinct educational levels have been subjected to systematic and unsystematic observations, respectively. It raises an authentic phonology-related problem in ELT and EFL learning, herein the mispronunciation of the phoneme/s/ between two vowels sounds in many words. Definitely, such phenomenon has resulted from the long term of acculturation between Arabic and French and then shifted into linguistic contact between French and English in the country. This situation has deeply affected the pronunciation ability of both the Algerian English language teachers and learners.

Albeit this study comes across looking closely at the reasons that lie behind the occurrence of such error in pronunciation, it touches the very heart of the problem and provides some solutions that might possibly alleviate it. To put it another way, this paper hopes to offer the opportunity for both EFL learners and their teacher in Algeria to refine particularly their pronunciation of the sound /s/ in many words and to improve their accent in the target language in general. First, it is inferred that the communicative side of language inside EFL classrooms has mainly been hindered by the pedagogical straightjackets in the sense that the language education policy and/or curricula designers have emphasized reading and writing while the speaking and listening skills are ignored. This can be perceived by the fact that textbooks are overloaded with reading comprehension passages followed by related grammatical tasks and activities, which are all intended just for producing a piece of writing as an ultimate objective. Obviously, such a strategy has been adopted for decades in designing all the formative exams whereby the speaking and even the listening skills are totally neglected.

Second, it is also concluded - on the one hand- that most EFL teachers in all educational levels seem to follow attentively both the written pedagogical directions involved in curricula or syllabi (which are all restated in textbooks) and the oral instructions of their inspectors or Principals. By the time, the large majority of teachers have become just 'textbooks' slaves', who have never bothered themselves about adding their personal touch and/or creativity within their classrooms. On the other hand, some teachers have struggled to invent their own visual aids and/or scaffolding new strategies to be used with their EFL learners to have the required proficiency in the target language. For the sake of improving their students' speaking/pronunciation ability, some EFL teachers have focussed much on listening, especially via begging native speakers to help them recording audios or videos on particular situations, recommending them to watch films, listen to interviews or short audio stories in the target language, etc., asking learners to repeat difficult words often, encouraging learners to speak even if they commit errors rather than being hidden, referring them to phonemic symbols so as they will be able to read dictionary entries or use them to check words that they find difficult to pronounce or have heard for the first time, etc.

Third, it is unfortunately noticed that the large majority of EFL learners are passive, ready-made knowledge seekers, who take everything for granted, and most of the time, unconsciously imitate their teachers' erroneous pronunciations. However, very few are hardworking learners, who have a sense of curiosity about everything; they tend to ask a lot of questions, keep closer to their teachers, ask for references, etc. They possess dictionaries in which they usually a look at them whenever they have doubts about words' meanings or pronunciations, they have always tried to improve their pronunciations via exploiting each and every social networking sites to imitate, listen to, chat, or exchange ideas with the native speakers and even sometimes they infer the variations between the different varieties of the target language in terms of pronunciation, spelling, vocabulary, grammar and punctuation.

Last but not least, none can deny the fact that the blame of mispronouncing English in the Algerian context is a tripled shared issue that can be solved like any other language-related problem. It must be noted that (T)EFL pronunciation is not as easy as drinking a glass and not as difficult as touching the sky because loving learning or teaching pronunciation are just mixed matters of willingness, getting started and perseverance with a sense of valuing accompaniment and teaching responsibility.

To make the long story short, the phenomenon of mispronouncing the phoneme /s/ is not just hair splitting: if contact-induced phonological change in such or other sounds takes place in the speech of EFL learners and teachers in Algeria, it will directly lead to other morpho-syntactic and semantic problems.

Beyond the shadow of a doubt, such error in pronunciation and others in EFL classrooms in Algeria could be solved if, first, decision makers throughout curricula designers have seriously taken into their account in-service teachers' ideas and views and mainly research raised by practitioners in EFL learners' phonology-related problems. On the one side, this requires a complete rethinking of the significance of the speaking skill in textbooks' contents in tandem with the possibility of its inclusion in the typology for formative exams in secondary education. On the other side, it necessitates looking for alternative teaching methods 
or strategies and the reconsideration of the teaching contents of the 'listening and speaking' and 'phonetics and phonology' modules together with their weekly scheduled teaching hours of each at the university level. Second, if teachers keep on upgrading their speaking skill and/or updating their pronunciation ability through effective exploitation of the current ICTs, and making the best use inside their classrooms. Third, if learners are only too eager to improve their pronunciations via giving ears to native speakers' accent or making the dictionary their intimate friend in pronunciation i.e. a timely checking tool.

This study might be a model in generating a number of linguistic theories for further empirical investigations using different population and qualitative research methods. In other words, this enquiry might be a reference for other promising areas of research especially in the arena of phonology within the Algerian context including teaching and/or learning the pronunciation of some (un)familiar clusters, diagraphs, invisible letters, metathesis, phonemic overlapping, phonemic orthography, etc.

\section{References}

[1] Berrabah, A. (2014). The ideological beliefs towards code switching/mixing practices and their effects on communication efficiency via 'sms language' in Relizane: a critical discourse analysis. [Unpublished thesis of Magister]. University of Oran.

[2] Benrabah, M. (2007). The language planning situation in Algeria". In Richard B. Baldauf,Robert B. Kaplan (eds.) language planning and policy, Africa, Vol. 2: Algeria, Côte d'Ivoire, Nigeria, and Tunisia. 25-148.

[3] Bouamrane, A. (1986). Aspect of the sociolinguistics situation in Algeria, [Unpublished PhD Thesis], Aberdeen University. Great Britain.

[4] Boucherit, A. (2002). "Algérie: de l'Arabe à l'Arabisation", Language contact and language conflict in arabic. Variations on a sociolinguistic theme, Routledge Curzon, pp. 54- 69

[5] Bouhadiba, F. (2002). "Language at Work: A case Study," Revue Maghrébine des langue I, pp. 13- 29

[6] Labov, W. (1972). Sociolinguistic patterns .Oxford: Blackwell.

[7] Louznadji, M. (2003). English: open doors (3eme AS). Oran: Ibn Khaldoun House of Publication. Algeria.

[8] Miliani, M. (2000). Teaching english in a multilingual context: the Algerian case. In Mediterranean Journal of Educational Studies, 6 (1), $13-29$.

[9] Mostari, H.A. (2005). The language question in the Arab world: evidence from Algeria, Journal of Language and Learning, 3 (1), $36-52$.

[10] Roach,P. (2000). English phonetics and phonology: a practical course (3rd edition). CUP, England

[11] Roach,P., Hartman, J., Setter, J. \& Jones, D. (2006). Cambridge english pronouncing dictionary 18th Edition. Cambridge : Cambridge University Press.

[12] Sankoff, G. (2002). Linguistic outcomes of language contact. In The handbook of language variation and change, J.K. Chambers, P. Trudgill \& N. Schilling-Estes (eds), 638-668. Oxford: Blackwell.

[13] Thomason, S.G. (2001a). Language contact: an introduction. Edinbourg: Edinburg University Press.

[14] Thomason, S.G. (2001b). Contact-induced typological change. In Language typology and language universals, Sprachtypologie und sprachliche Universalien,Volume 2, 2. Halbband, Tome 2, M. Haspelmath, E. Koenig, W. Oesterreicher \& W. Raible (eds), 1640-1648. Berlin/New York: Walter de Gruyter.

[15] Thomason, S.G. \& Kaufman, T. (1988). Language contact, creolization, and genetic linguistics. Berkeley and Los Angeles: University of California Press.

[16] Weinreich, U. (1953). Languages in contact. The Hague: Mouton. 